\title{
Assimilation of lactitol, an 'unabsorbed' disaccharide in the normal human colon
}

\author{
G K GRIMBLE, D H PATIL, AND D B A SILK \\ From the Department of Gastroenterology and Nutrition, Central Middlesex Hospital, London
}

SUMmARY The fate of orally ingested lactitol, a non-absorbed sugar, was measured in six healthy human subjects by following the three routes of disposal of universally ${ }^{14} \mathrm{C}$-labelled sugar. Lactitol was given as a $20 \mathrm{~g}$ daily dose to six healthy volunteers for 14 days and on the seventh day, $10 \mu \mathrm{Ci}$ of $\mathrm{L}-\left[\mathrm{U}-{ }^{14} \mathrm{C}\right]$-lactitol was given with the unlabelled sugar and excretion of the ${ }^{14} \mathrm{C}$ in breath, urine and faeces was followed. The peak of ${ }^{14} \mathrm{CO}_{2}$ excretion occurred at six hours and total ${ }^{14} \mathrm{CO}_{2}$ accounted for $62.9(5.0) \%$ of isotope given, whilst $6 \cdot 5(3.6) \%$ and $2.0(0 \cdot 3) \%$ of the label were recovered from faeces and urine respectively. These data suggest that lactitol is extensively metabolised in the human colon and that a significant proportion of the bacterial metabolites are available for colonic absorption. Calculation revealed that $54 \cdot 5 \%$ of the theoretical energy content of this compound was utilised by the subjects. It is suggested that this sugar, and other soluble 'non-absorbed' sugars (lactulose, sorbitol, mannitol), may undergo a similar pattern of colonic metabolism and can be considered as reduced calorie compounds.

Lactitol, [4-O(beta-D-galactopyranosyl)-D-glucitol], is a disaccharide alcohol prepared by hydrogenation of lactose. ${ }^{2}$ Small intestinal perfusion studies have shown that no significant absorption of lactitol occurs in man. ${ }^{3}$ In the light of its favourable physicochemical and taste properties, this would suggest that lactitol could be substituted for sucrose and glucose syrups, as a low calorie, bulk sweetener and humectant for foodstuffs. Dietary carbohydrate entering the colon $^{410}$ is salvaged through the action of colonic bacteria, by metabolism to volatile fatty acids (VFA's) which may be absorbed by the colon..$^{11-13}$ In vitro incubation experiments have confirmed that human faecal bacteria can metabolise lactitol to VFA's ${ }^{14}$ and we have shown that the luminal contents of the right side of the human colon are acidified, following oral ingestion of lactitol. ${ }^{14}$

As VFA's are avidly absorbed from the colon and utilised as a primary energy substrate by colonic mucosa, and other tissues, ${ }^{11315}$ metabolic pathways

Address for correspondence: Dr D B A Silk, Department of Gastroenterology and Nutrition, Central Middlesex Hospital, London.

Received for publication 8 June 1988. therefore exist, in man, for converting unabsorbed lactitol into utilisable moieties.

The rate of conversion and uptake of lactitol, ${ }^{1617}$ and similar compounds (sorbitol, mannitol, maltitol and palatinit ${ }^{18-20}$ is poorly defined and it is not known whether they should be considered as a 'low calorie' substitute for sucrose and glucose syrups. The aim of the present study, therefore, has been to investigate the fate and quantitative metabolism of lactitol following oral ingestion of the universally ${ }^{14} \mathrm{C}$ labelled sugar at sublaxative doses.

\section{Methods}

\section{STUDY DESIGN}

In the first part of the study (adaptation), six healthy volunteers (four men, two women, age 25-43 years) who were consuming their normal diet and not on any concurrent medication, received $20 \mathrm{~g}$ of lactitol daily (dissolved in $150 \mathrm{ml}$ of water), after breakfast, for seven days. On the eighth day, $10 \mu \mathrm{Ci}$ universally labelled ${ }^{14} \mathrm{C}$-lactitol (D-[U- $\left.{ }^{-14} \mathrm{C}\right]$ lactitol, $14 \mu \mathrm{Ci} / \mathrm{mmol}$, Amersham International, Bucks, UK) was given with the unlabelled lactitol and for the next seven 
days, $20 \mathrm{~g}$ unlabelled lactitol was given daily. Excretion of ${ }^{14} \mathrm{C}$ in $\mathrm{CO}_{2}$, faeces and urine were followed over the next seven days. Before the study, the background level of labelling in breath $\mathrm{CO}_{2}$, faeces and urine was measured.

\section{$\mathrm{CO}_{2}$ MEASUREMENTS}

Subjects inflated a modified, disposable urine bag (with non-return flap-valve) via a drying tube containing calcium chloride (3-8 mesh). The sample of collected expired air was gently bubbled through $3 \cdot 0$ $\mathrm{ml}$ of a solution containing $1.0 \mathrm{ml}$ of hyamine hydroxide $(1.0 \mathrm{~mol} / \mathrm{l}), 2.0 \mathrm{ml}$ ethanol and phenolphthalein as indicator, until the solution became colourless, whereupon $5.0 \mathrm{ml}$ of scintillation fluid (Beckman Readysolv-MP) was added. The $\mathrm{CO}_{2}$ absorbing capacity of each batch of ethanolic hyamine hydroxide solution was checked by titration against a volumetric solution of $0.1 \mathrm{~mol} / \mathrm{HCl}$. Radioactivity was assayed by liquid scintillation counting (Beckman LS 7500, Beckman, High Wycombe, Bucks, UK) with quench correction by the H-Number method. Breath samples were taken $1,2,3,4,5,6,7,8,9,10,12,14,24,36,48$ hours and $3,4,5,6$ and 7 days after ${ }^{14} \mathrm{C}$ lactitol administration. Steady state $\mathrm{CO}_{2}$ production rates (normalised to STP) were measured, using an indirect calorimeter, built according to the design of Clugston, ${ }^{21}$ to a precision better than $\pm 0 \cdot 5 \%$.

The steady state ${ }^{14} \mathrm{CO}_{2}$ output corrected for incomplete recovery (see below) was calculated as the product of $\mathrm{CO}_{2}$ specific activity $\left(\mathrm{dpm} / \mu \mathrm{mol}^{-1}\right)$ and $\mathrm{CO}_{2}$ output $(\mu \mathrm{mol} / \mathrm{h})$.

URINE ANALYSIS

Urine was collected, for 24 hour periods, in containers to which $5 \mathrm{ml} 10.0 \mathrm{~mol} / \mathrm{l} \mathrm{NaOH}$ had been added. Samples of the urine $(2.0 \mathrm{ml})$ were neutralised by titration with $0.1 \mathrm{~mol} / \mathrm{l} \mathrm{HCl}$ using phenolphthalein as indicator, $5.0 \mathrm{ml}$ scintillation fluid was added and radioactivity assayed as described.

FAECAL ANALYSIS

Twenty four hour faecal samples were collected in thick walled polyethylene bags and frozen immediately. Each frozen sample was homogenised in an equal volume of distilled water and a $1.0 \mathrm{~g}$ aliquot of homogenate was incubated with $2.0 \mathrm{ml}$ of $0.45 \mathrm{~mol} / \mathrm{l}$ $\mathrm{NaOH}$ for two hours at $60^{\circ} \mathrm{C}$ in a tightly capped scintillation vial. Samples were decolourised by addition of $1.5 \mathrm{ml}$ of $5.0 \% \mathrm{NaOCl}$ (domestic bleach Melzone), incubated at $60^{\circ} \mathrm{C}$ for 20 minutes and excess chlorine removed by brief vacuum treatment. A stable gel was formed by addition of $3.0 \mathrm{ml}$ water and $10 \mathrm{ml}$ Readysolv-MP and scintillation vials were stored in the dark for five days to allow decay of chemiluminescence. This method produces scintillation gels which are stable for more than three weeks (with no detectable loss of ${ }^{14} \mathrm{C}$ ) and avoids the need for expensive combustion apparatus to measure faecal ${ }^{14} \mathrm{C}$ as ${ }^{14} \mathrm{CO}_{2}$. Efficiency of counting was $60 \%$ and $80 \%$, partially- and fully-decolourised gels, respectively, and reproducibility was $\pm 0.8 \%$ and $\pm 2.0 \%$ for samples containing $10000 \mathrm{dpm}$ and 100 dpm, respectively.

\section{CALCULATION OF RESULTS}

The metabolic fate of universally labelled lactitol was followed. During the course of the experiments, the possible routes of ${ }^{14} \mathrm{C}$ disposal were, breath $\left({ }^{14} \mathrm{CO}_{2}\right)$, urine and faeces.

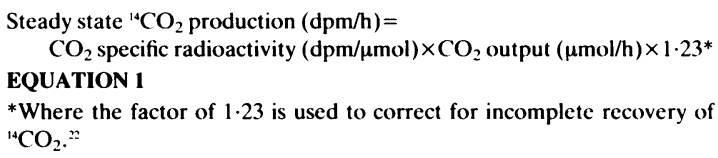

*Where the factor of 1.23 is used to correct for incomplete recovery of ${ }^{14} \mathrm{CO}_{2} \cdot{ }^{2 "}$

\section{Results}

Ingestion of $20 \mathrm{~g}$ of lactitol during the course of this experiment did not have a cathartic effect. Average stool weight (Table 1) was $306.5(91 \cdot 6) \mathrm{g} /$ day (mean $(\mathrm{SE})$ ) and it had been noted in a previous study, with the same volunteers, that $20 \mathrm{~g}$ bolus dose of lactitol did not exceed the laxative threshold for each subject. ${ }^{3}$ The time from ingestion to peak ${ }^{14} \mathrm{CO}_{2}$ excretion averaged six hours (Fig. 1) and Table 2

Table 1 Subject details and faecal output during course of the study

\begin{tabular}{llll}
\hline Subject & Sex & Age & Average faecal output \\
\hline A & M & 34 & $142 \cdot 0(18 \cdot 0)$ \\
B & M & 35 & $446 \cdot 5(90 \cdot 1)$ \\
C & M & 34 & $683 \cdot 0(28 \cdot 2)$ \\
D & M & 40 & $240 \cdot 0(72 \cdot 5)$ \\
E & F & 30 & $218 \cdot 7(51 \cdot 0)$ \\
F & F & 30 & $109 \cdot 0(27 \cdot 2)$ \\
Mean (SE) & & & $306 \cdot 5(91 \cdot 6)$ \\
\hline
\end{tabular}

Table $2{ }^{14} \mathrm{C}$ recovery after $\left(U-{ }^{14} \mathrm{C}\right)$-lactitol administration

\begin{tabular}{|c|c|c|c|c|}
\hline \multirow[b]{2}{*}{ Subject } & \multicolumn{4}{|c|}{ Values are expressed as $\%$ of ingested dose } \\
\hline & Faeces & Urine & Breath & Total \\
\hline A & $2 \cdot 4$ & $3 \cdot 2$ & $78 \cdot 2$ & $83 \cdot 8$ \\
\hline B & $22 \cdot 5$ & 1.7 & $44 \cdot 6$ & $68 \cdot 7$ \\
\hline C & $10 \cdot 9$ & $2 \cdot 0$ & $52 \cdot 6$ & $65 \cdot 5$ \\
\hline D & $2 \cdot 2$ & 1.8 & $64 \cdot 2$ & $68 \cdot 2$ \\
\hline E & $0 \cdot 8$ & 1.9 & $69 \cdot 1$ & $71 \cdot 8$ \\
\hline $\mathrm{F}$ & 0.4 & 1.5 & $68 \cdot 6$ & $70 \cdot 5$ \\
\hline Mean (SE) & $6 \cdot 5(3 \cdot 6)$ & $2 \cdot 0(0 \cdot 25)$ & $62.9(5.0)$ & $71 \cdot 4(2 \cdot 63)$ \\
\hline
\end{tabular}




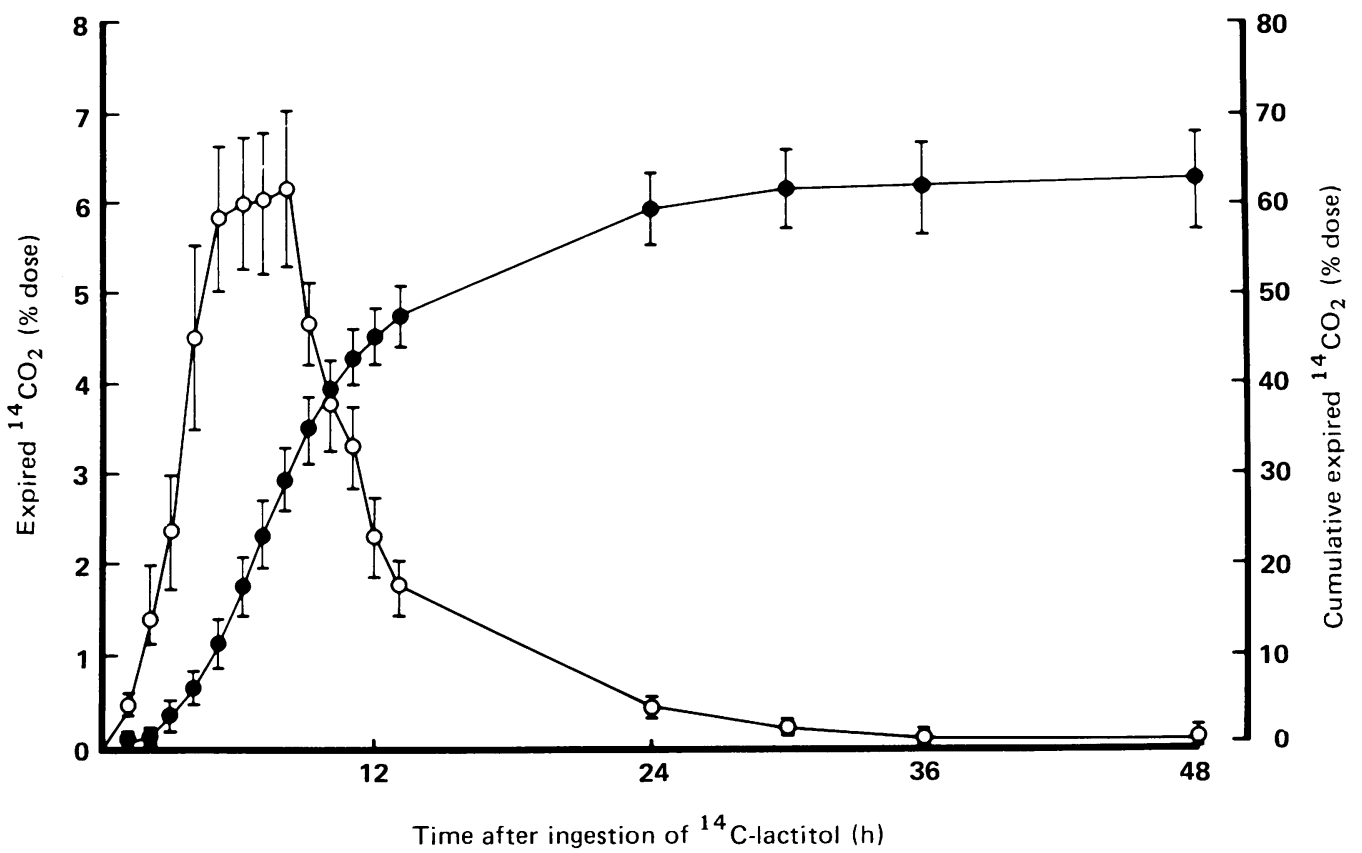

Fig. 1 Time course of excretion of ${ }^{14} \mathrm{CO}_{2}$ in six healthy subjects after an oral dose of $D-\left[U \cdot{ }^{14} \mathrm{C}\right]$ lactitol and $20 \mathrm{~g}$ unlabelled lactitol. Results are expressed as \% of dose/h (O), and cumulative excretion of dose, \%, (O). Values represent the average and standard errors of the mean are represented by the vertical bars.

summarises the individual values for ${ }^{14} \mathrm{C}$ excretion in breath, faeces and urine over a period of three days. Total recovery of ${ }^{14} \mathrm{C}$ was mean $71.4 \%(2.6)$ and $88.1 \%$ of recovered ${ }^{14} \mathrm{C}$ was in the form of expired $\mathrm{CO}_{2}$ and $6.5 \%$ in stool (Table 2). Urinary excretion of ${ }^{14} \mathrm{C}(2.0 \%(0.25)$ of ingested dose $)$ was not in the form of $\mathrm{HCO}_{3}{ }^{-}$, because $\mathrm{Na}_{2} \mathrm{CO}_{3}$ addition to samples and subsequent acidification did not reduce ${ }^{14} \mathrm{C}$ content.

There was such rapid clearance of label through all three routes (Table 3) that it was not possible to detect ${ }^{14} \mathrm{CO}_{2}$ in breath after two days, at the level of sensitivity of the method $(<0.05 \%$ of dose given). As will be discussed, we calculate that of ingested ${ }^{14} \mathrm{C}$ lactitol, $2 \%$ was passively absorbed in the small bowel (appearing in urine) and $98 \%$ entered the colon. Assuming that bacterial metabolism resulted in loss of $28 \%$ of the lactitol carbon entering the colon as $\mathrm{CO}_{2}(27.4 \%$ of the dose $)$, the remaining ${ }^{14} \mathrm{C}$ ( $64.1 \%$ of the dose), was either absorbed by colonic mucosa as VFA's or excreted in faeces $(6.5 \%$ of dose). The absorbed fraction was not all metabolised directly to ${ }^{14} \mathrm{CO}_{2}$, instead we calculate that $28.6 \%$ of the dose was incorporated into nonlabile whole-body metabolites (the retained fraction) whilst $35.5 \%$ of the dose was completely metabolised, endogenously, to ${ }^{14} \mathrm{CO}_{2}$.

\section{Discussion}

The colonic microflora have a large capacity to metabolise malabsorbed dietary carbohydrate and breath hydrogen studies suggest that up to $20 \%$ of starch may be handled in this way. ${ }^{4710^{1323}}$ Even well absorbed carbohydrates, such as glucose, instilled directly into the large intestine, are fermented at a rate exceeding that of passive colonic absorption. ${ }^{24} 25$ As orally administered lactitol promotes acidification of the right colon ${ }^{14}$ in a similar fashion to lactulose, ${ }^{26}$ it can therefore be considered along with other nonabsorbed carbohydrates which are metabolised, primarily by colonic fermentation.

Energy balance studies in man have suggested that

Table 3 Time course of ${ }^{14} \mathrm{C}$ recovery after $\left(U-{ }^{14} \mathrm{C}\right)$-lactitol administration

\begin{tabular}{rlllr}
\hline & \multicolumn{4}{l}{ Values are expressed as \% of ingested dose } \\
\cline { 2 - 5 } Time $(h)$ & Faeces & Urine & \multicolumn{1}{c}{ Breath } & \multicolumn{1}{l}{ Total } \\
\hline $0-24$ & $5 \cdot 73(3 \cdot 58)$ & $1 \cdot 49(0 \cdot 20)$ & $59 \cdot 33(4 \cdot 35)$ & $66 \cdot 56(2 \cdot 75)$ \\
$24-48$ & $0 \cdot 50(0 \cdot 16)$ & $0 \cdot 38(0 \cdot 04)$ & $3 \cdot 55(1 \cdot 17)$ & $4 \cdot 44(1 \cdot 12)$ \\
$48-72$ & $0 \cdot 25(0 \cdot 10)$ & $0 \cdot 11(0 \cdot 03)$ & & $0 \cdot 36(0 \cdot 26)$ \\
\hline
\end{tabular}

Mean (SE) 
approximately $50 \%$ of the energy content of lactitol is available for endogenous metabolism, compared with sucrose. ${ }^{17}$ In this type of study, correction is made for differences in activity patterns between groups of subjects before extrapolating energy expenditure to dietary intakes consisting entirely of the sugars under study. The principles and limitations of this method are discussed in detail elsewhere. ${ }^{27} \mathrm{We}$ have used an alternative method, with different assumptions and limitations, to calculate the metabolic utilisation of lactitol. In brief, these assumptions are: (1) All ${ }^{14} \mathrm{CO}_{2}$ produced by endogenous and exogenous metabolism of lactitol must be measured. (2) There should be no significant, undetected, loss of ${ }^{14} \mathrm{CH}_{4}$ and ${ }^{14} \mathrm{CO}_{2}$ in flatus. (3) Faecal excretion of intact ${ }^{14} \mathrm{C}$-lactitol should be minimal. (4) Faecal collection should be complete.

Values for ${ }^{14} \mathrm{CO}_{2}$ excretion were corrected for incomplete recovery due to hold up in non-labile $\mathrm{CO}_{2}$ pools as described before ${ }^{22}$ and shown in Equation 1.

Although the colonic mucosa is only marginally permeable to $\mathrm{H}_{2}{ }^{28}$ and $\mathrm{CH}_{4}$ (only $14 \% \mathrm{H}_{2}$ appears in breath, the remainder being expelled in flatus), it is likely that $\mathrm{CH}_{4}$ production represents only a small proportion of metabolised carbon. ${ }^{817}$ Absorption of $\mathrm{CO}_{2}$ is, however, rapid as observed at colonoscopy and calculation of flatus losses, based on the labelling of the administered lactitol and the rate of flatus production and its $\mathrm{CO}_{2}$ content in subjects consuming a highly flatogenic diet, ${ }^{56}$ indicates that less than $3 \%$ of ${ }^{14} \mathrm{CO}_{2}$ would have been excreted through this route during the first day of the study.

We have assumed that little intact ${ }^{14} \mathrm{C}$-lactitol was excreted in faeces ${ }^{29}$ and presumably, faecal excretion of ${ }^{14} \mathrm{C}$ represents isotope incorporated into the faecal bacterial mass.

Finally, we have assumed that faecal collection was complete. All studies were carried out on motivated volunteers within the hospital and given the small recovery of ${ }^{14} \mathrm{C}$ in faeces, an error here would not significantly affect the estimate of ${ }^{14} \mathrm{C}$ excretion by this route. Finally, the proportion of ${ }^{14} \mathrm{C}$-lactitol which was excreted in the urine represents the amount absorbed from the gastrointestinal tract by passive diffusion (Fig. 2) and has thus been subtracted from the ingested dose to give the amount which entered the large bowel. The overall stochiometry of colonic fermentation of carbohydrate has been described, ${ }^{30}$ according to the equation:-

$34 \cdot 5 \mathrm{C}_{6} \mathrm{H}_{12} \mathrm{O}_{6}+37 \cdot 0 \mathrm{H}_{2} \mathrm{O} \longrightarrow$
48 acetate $+58 \cdot 0 \mathrm{CO}_{2}$

EQUATION 2

Thus, $28 \%$ of the lactitol carbon would have been released as $\mathrm{CO}_{2}$ during colonic conversion to VFA's and, because little intact ${ }^{14} \mathrm{C}$-lactitol was excreted in

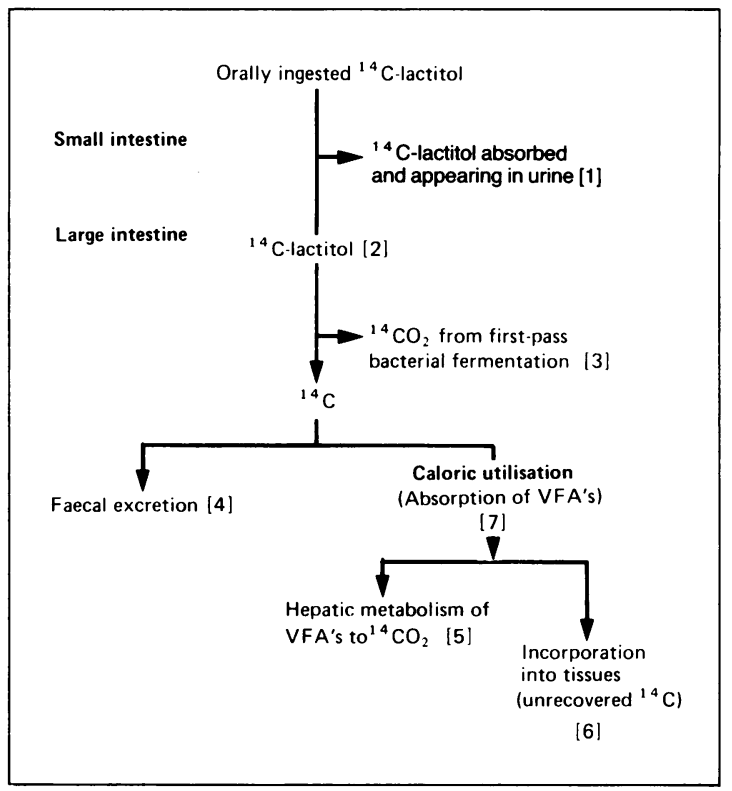

Fig. 2 Calculation of the quantitative routes of disposal of orally ingested ${ }^{14} \mathrm{C}$-lactitol. $[1]{ }^{14} \mathrm{C}$-lactitol absorbed and appearing in urine. $[2]{ }^{14} \mathrm{C}$-lactitol entering colon $={ }^{14} \mathrm{C}$ lactitol ingested $-{ }^{14} \mathrm{C}$ in urine. $[3]{ }^{14} \mathrm{CO}_{2}$ produced from bacterial fermentation $=28 \%$ of ${ }^{14} \mathrm{C}$-lactitol entering colon. [4] Faecal excretion of ${ }^{14} \mathrm{C}$. [5] Hepatic metabolism of ${ }^{14} \mathrm{C}$ $V F A$ 's = total measured ${ }^{14} \mathrm{CO}_{2}-{ }^{14} \mathrm{CO}_{2}$ from bacterial fermentation [3]. [6] Unrecovered ${ }^{14} \mathrm{C}$. [7] Caloric utilisation=hepatic production of ${ }^{14} \mathrm{CO}_{2}[5]+$ unrecovered ${ }^{14} \mathrm{C}[6]$.

faeces, $28 \%$ of the fermentable ${ }^{14} \mathrm{C}$-labelled sugar which had entered the colon was released as ${ }^{14} \mathrm{CO}_{2}$ by bacterial action. Of the remainder, part would be absorbed as ${ }^{14} \mathrm{C}$-VFA's (to undergo further oxidative and interconvertive metabolism), part metabolised endogenously by the colonic mucosa to ${ }^{14} \mathrm{CO}_{2}$ and non-labile ${ }^{14} \mathrm{C}$-metabolites, and part incorporated into bacteria or excreted as ${ }^{14} \mathrm{C}$-VFA's in the faeces (Fig. 2). The proportion of ${ }^{14} \mathrm{CO}_{2}$ produced by microbial fermentation of lactitol to VFA's can be calculated as $27.4 \%$ of the ingested ${ }^{14} \mathrm{C}$ dose (Equation 2 and Fig. 2). The remaining ${ }^{14} \mathrm{CO}_{2}$ must have come from endogenous oxidative metabolism and accounts for $35.5 \%$ of ingested ${ }^{14} \mathrm{C}$-lactitol carbon. A proportion $(28.6 \%)$ of ${ }^{14} \mathrm{C}$ could not be accounted for, and this may represent ${ }^{14} \mathrm{C}$ - VFA's absorbed and metabolically incorporated by the colonocytes or by other tissues in the body. On this basis, we would calculate that $64 \cdot 1 \%$ $(28 \cdot 6 \%+35 \cdot 5 \%)$ of the ${ }^{14} \mathrm{C}$ of orally ingested ${ }^{14} \mathrm{C}$ lactitol was available for further metabolism by the subjects themselves. Oxidative metabolism of VFA's 
produces $15 \%$ less ATP per calorie than glucose ${ }^{27}$ and the energy yield of absorbed VFA's in this study was therefore $64.1 \% \times 0.85$, or $54.5 \%$ of the energy content of lactitol. We believe that this technique is robust if the carbohydrate under test is extensively metabolised in the large bowel. If a test substance undergoes modest colonic metabolism $\left({ }^{14} \mathrm{CO}_{2}\right.$ output low) and high faecal excretion of ${ }^{14} \mathrm{C}^{831}$ the proportion of faecal ${ }^{-14} \mathrm{C}$ present as intact ${ }^{14} \mathrm{C}$-carbohydrate or ${ }^{14} \mathrm{C}$-VFA should be measured, so that the value for bacterial $\mathrm{CO}_{2}$ production can be subtracted from total ${ }^{14} \mathrm{CO}_{2}$ in the calculation.

Three points may be made about these results. First, a wide variation in faecal output of ${ }^{14} \mathrm{C}$ was noted which may relate to differences in dietary intake. All subjects were interviewed about their diet and in the case of subject (B), an Indian national who was consuming a vegetarian diet, faecal ${ }^{14} \mathrm{C}$ output was high, whereas a West Indian subject (A), consuming a high fat, low residue diet had small faecal output, low faecal ${ }^{14} \mathrm{C}$ excretion and a high ${ }^{14} \mathrm{CO}_{2}$ output. The remaining caucasian subjects had intermediate values for faecal ${ }^{14} \mathrm{C}$ and ${ }^{14} \mathrm{CO}_{2}$ with one exception. The caloric utilisation of lactitol, for any individual, may therefore be influenced by preexisting dietary habits and fibre intake. Conversely, chronic, sublaxative consumption of lactitol may alter utilisation of natural, malabsorbed dietary carbohydrates since it can alter bowel habit. ${ }^{3}$ Moderate intakes of other non-absorbed sugars decrease transit time and increase faecal output and nitrogen content. ${ }^{18}{ }^{19}$ Under these circumstances, a loss of energy to the large bowel from VFA's produced by fermentation of natural dietary carbohydrates may be offset by VFA's, released by avid metabolism of lactitol itself. The true caloric utilisation of lactitol, under such circumstances may be less than our estimate of $54.5 \%$ or $2 \cdot 2 \mathrm{kcal} / \mathrm{g}$.

Although malabsorbed carbohydrate may have a protective effect on the large bowel, ${ }^{23}$ this should be balanced against the effects of ingestion of large quantities of non-absorbed sugars. Substitution of lactitol for sucrose and glucose syrups in confectionery and foodstuffs, may lead to intakes approaching the laxative threshold (up to $70 \mathrm{~g} /$ day), ${ }^{3}$ and produce symptoms such as bloating, diarrhoea, excessive flatus, and abdominal cramps. Although the strategy of substituting lactitol for sugar in foodstuffs is undoubtedly good for teeth, ${ }^{32}$ and the pancreas, ${ }^{29}$ it may not produce socially acceptable bowel habits.

We would therefore conclude from the present study that the pattern of small and large bowel handling of lactitol reduced its potential energy yield by $45 \%$. In this respect, it can be considered as a reduced calorie substitute for sucrose and glucose syrups.
We are grateful to Express Dairies (UK) Ltd for financial support and encouragement and to Amersham International for custom synthesis of universally ${ }^{14} \mathrm{C}$-labelled lactitol.

\section{References}

1 van Velthuijsen JA. Food additives derived from lactose: lactitol and lactitol palmitate. J Agric Food Chem 1979; 27: 680-6.

2 Hayashibara KK. Containing lactitol as a sweetener. USA Patent No. 3973050: 1976 August 3rd.

3 Patil DH, Grimble GK, Silk DBA. Lactitol, a new hydrogenated lactose derivative: intestinal absorption and laxative threshold in normal human subjects. $\mathrm{Br} J$ Nutr 1987; 57: 195-9.

4 Stephen AM, Haddad AC, Phillips SF. Passage of carbohydrate into the colon: Direct measurements in humans. Gastroenterology 1983; 85: 589-95.

5 Hickey CA, Murphy EL, Calloway DH. Intestinal-gas production following ingestion of commercial wheat cereals and milling fractions. Cereal Chem 1972; 49: 276-83.

6 Fleming SE, Calloway DH. Determination of intestinal gas excretion. In: Birch GG, Parker KJ, eds. Dietary fibre. London: Applied Science Publishers, 1983: 22154.

7 Anderson IH, Levine AS, Levitt MD. Incomplete absorption of the carbohydrate in all-purpose wheat flour. N Engl J Med 1981; 304: 891-2.

8 Kelleher J, Walters MP, Srinivasan TR, Hart G, Findlay JM, Losowsky MS. Degradation of cellulose within the gastrointestinal tract in man. Gut 1984; 25: 811-5.

9 Cummings JH. Cellulose and the human gut. Gut 1984; 25: 805-10.

10 Levine AS, Levitt MD. Malabsorption of starch moiety of oats, corn and potatoes [Abstract]. Gastroenterology 1981; 80: 1209.

11 Parker DS. The measurement of production rates of volatile fatty acids in the caecum of the conscious rabbit. Br J Nutr 1976; 36: 61-70.

12 McNeill NI, Cummings JH, James WPT. Short chain fatty acid absorption by the human large intestine. Gut 1978; 19: 819-22.

13 McNeill NI. The contribution of the large intestine to energy supplies in man. Am J Clin Nutr 1984; 39: 33842.

14 Patil DH, Westaby D, Mahida YR, et al. Comparative modes of action of lactitol and lactulose in the treatment of hepatic encephalopathy. Gut 1987; 28: 255-9.

15 Marty JF, Vernay MY, Abravanel GM. Acetate absorption and metabolism in the rabbit hindgut. Gut 1985; 26: 562-9.

16 Bird SP, Hewitt D, Gurr MI. Digestible and metabolisable energy values of lactitol and lactulose for the rat and miniature guinea-pig [Abstract]. Proc Nutr Soc 1985; 44: 40A.

17 van Es AJH, De Groot L, Vogt JE. Energy balances of eight volunteers on diets with either lactitol or saccharose. Br J Nutr 1986; 56: 545-54.

18 Wiggins HS. Nutritional value of sugars and related 
compounds undigested in the small gut. Proc Nutr Soc 1984; 43: 69-75.

19 Saunders DR, Wiggins HS. Conservation of mannitol, lactulose and raffinose by the human colon. Am J Physiol 1981; 241: G397-402.

20 Wursch P, Schweizer T. Breath hydrogen after ingestion of three disaccharide alcohols and lactulose. Proceedings of Zuckersymposium Karies und Zucker. 12-13th June 1986, Wurzburg, FRG. Dtsch Zahnarztl 1987; Z42: 151-3.

21 Clugston GA. Energy and protein metabolism in obese subjects. University of London: PhD Thesis, 1981.

22 James WPT, Garlick PJ, Sender PM, Waterlow JC. Studies on amino acid metabolism in normal man with $\mathrm{L}\left(\mathrm{U}^{14} \mathrm{C}\right)$ tyrosine. Clin Sci Mol Med 1976; 50: 525-32.

23 Thornton JR, Dryden A, Kelleher J, Losowsky MS. Does super-efficient starch absorption promote colonic neoplasia? [Abstract]. Gut 1985; 26: A554.

24 Long CL, Geiger JW, Kinney JM. Absorption of glucose from the colon and rectum. Metabolism 1967; 16: 413-8.

25 Bond JH, Levitt MD. Fate of soluble carbohydrate in the colon of rats and man. J Clin Invest 1975; 57: 115864.

26 Bown RL, Gibson JA, Sladen GE, Hicks B, Dawson AM. Effects of lactulose and other laxatives on ileal and colonic $\mathrm{pH}$ as measured by a radiotelemetry device. Gut 1974; 15: 999-1004.

27 van Es AJH. Energy utilization of low digestibility carbohydrates. In: Leegwater DC, Feron VJ, Hermus RJJ, eds. Low digestibility carbohydrates. Pudoc Wageningen 1987, 121-7.
28 Levitt MD, Levitt DG, Berggren T. Use of inert gases to study the interaction of blood flow and diffusion during passive absorption from the gastrointestinal tract of the rat. J Clin Invest 1973; 52: 1852-62.

$29 \mathrm{FAO} / \mathrm{WHO}$ Expert Committee on Food Additives. Toxicological evaluation of certain food additives and food contaminants. 27th report, April 1983. Geneva: FAO/WHO 1983. (WHO Technical Reports Series, no 696; Food Additives Series no 18: 82-94.)

30 Miller TL, Wolin MJ. Fermentations by saccharolytic intestinal bacteria. Am J Clin Nutr 1979; 32: 164-72.

31 Figdor SK, Bianchine JR. Caloric utilisation and disposition of $\left[{ }^{14} \mathrm{C}\right]$ polydextrose in man. J Agric Food Chem 1983; 31: 389-93.

32 Grenby TH, Desai T. The dental effects of lactitol replacing sucrose in confectionery examined in a clinical trial [Abstract]. Proc Nutr Soc 1988; 47: 2 A.

33 Roth FX, Kirchgessner M, Müller HL. Energetische verwertung von intracaecal infundierter essig- und propionsäure bei sauen. J Anim Physiol Anim Nutr 1988; 59: 211-7.

\section{Addendum}

A recent study of the energy yield of acetate and propionate instilled in the caecum of pigs, ${ }^{33}$ suggests that it may be $21-25 \%$ less than glucose, not $15 \%$ less as previously proposed. ${ }^{27}$ The potential energy yield of lactitol may therefore be closer to $50 \%$ than $55 \%$, as suggested above. 